\title{
Preface to Bjørn Sundby's Special Issue of Aquatic Geochemistry
}

\author{
Cédric Magen • Bruno Lansard - Sean A. Crowe
}

Received: 29 October 2012/Accepted: 7 November 2012

(C) Springer Science+Business Media Dordrecht 2012

This special issue of Aquatic Geochemistry is dedicated to the career of Bjørn Sundby (Fig. 1), Professor of Oceanography at the "Institut des Sciences de la Mer de Rimouski," Canada. Bjørn earned his PhD in physical organic chemistry from the University of Bergen (Norway) in 1966. He started his professional career as an organic chemist for the ColgatePalmolive Company, where he worked to develop novel phosphate-free detergents in the face of the looming eutrophication crisis. Exploring his diverse interests while at Colgate, Bjørn enrolled in oceanography classes at Rutgers University and fell in love with the subject. In pursuit of a career in Oceanography, he then moved to Dalhousie University in Halifax to take on a postdoctoral position with Doug Loring. During this time, he met his wife Danièle Godbout. Ultimately, Bjørn took up a position as an oceanography research associate at the Université du Québec à Rimouski from 1974 to 1980, before becoming Professor of Oceanography from 1980 to 1984. He then returned to Europe to head the Department of Chemical Oceanography and Marine Pollution at the Netherlands Institute for Sea Research from 1984 to 1987, before coming back to Canada as Director of the Physical and Chemical Oceanography Branch at the Maurice Lamontagne Institute, Department of Fisheries and Oceans, Canada. With a mass of scientific achievements under his belt, Bjørn earned a prestigious Dr. Philos. Degree in aquatic geochemistry from the University of Bergen in 1987. From 1992 to his retirement in 2010, he was Professor of Oceanography at the Institut des Sciences de la Mer de Rimouski, QC.

For nearly three decades, Bjørn has continued to challenge and change our view of sediment diagenesis, from the early models of a 1-dimensional steady-state system to our current picture of a 3D dynamic mosaic of biogeochemical reactions. One of his first major contributions was his work on manganese in the St. Lawrence Estuary. He was one of the

\author{
C. Magen $(\bowtie)$ \\ Department of EOAS, Florida State University, Tallahassee, FL 32306, USA \\ e-mail: cedric.magen@gmail.com \\ B. Lansard \\ LSCE, CNRS-CEA-UVSQ-IPSL, 91198 Gif-sur-Yvette, France
}

S. A. Crowe

Nordic Center for Earth Evolution, University of Southern Denmark, 5000 Odense, Denmark 
Fig. 1 A portrait of Bjørn

(Photo by D. Godbout)



first to recognize the potential importance of Mn to marine biogeochemistry, and his seminal papers elegantly illustrated how coastal sediments act as an important source of Mn for the deep ocean (Sundby 1977; Sundby et al. 1981). Given his diverse interests, Bjørn has worked extensively on a broad array of topics, including the marine phosphate cycle, processing of organic matter in permeable and soft sediments, transient diagenesis, the use of redox tracers as paleo indicators, micro-scale redox cycling in the rhizosphere, and the development of $\mathrm{Au} / \mathrm{Hg}$ amalgam microelectrodes for measuring redox species at fine spatial scales (Fig. 2). Bjørn held the prestigious position of President of the Scientific Committee on Oceanic Research (SCOR) from 2004 to 2008, where he shaped the focus of



Fig. 2 Bjørn and colleagues after investigating the organic complexation of $\mathrm{Mn}$ (III) and the nitrogen cycle during a cruise in the St. Lawrence Estuary in 2009. From left to right: George Luther, Al Mucci, Bjørn Sundby, and Brad Tebo (Photo by S. A. Crowe) 
international oceanographic research and informed marine policy. He remains an active member of SCOR's executive committee.

This special issue is to honor Bjørn's contribution to the field of chemical oceanography at a time when he is still very much active in science. Bjørn has certainly had a major influence on our young scientific careers, not only guiding us to the successful completion of our $\mathrm{PhD}$ theses, but also acting as both a mentor and friend. As an advisor, Bjørn was especially insistent on clear writing. Our discussions on the art of scientific writing, which typically took place over an espresso in Bjørn's office at McGill University, would often find examples in texts extruded from novels, newspaper articles, poetry, or classic articles that Bjørn found particularly well written. We cherish all the time spent with Bjørn in his office, often in the company of Alfonso Mucci (Fig. 3), pondering and discussing not only our research, but also food, wine, whiskey, and family.

The contributors to this special issue are all former students, colleagues, and friends of Bjørn's and, when asked, jumped at the opportunity to honor Bjørn's career in appreciation of his friendship and scientific leadership which mean so much to us all. The papers in this issue are diverse, reflecting Bjørn's enthusiasm for all things interesting. Lefort et al. (2012) examine 25 years of $\mathrm{Mn}, \mathrm{Fe}$, and As data to track the geochemical evolution of St. Lawrence Estuary sediments in response to hypoxia. The interactions of macrofauna with sediment biogeochemistry are studied in detail by two papers: Anschutz et al. (2012) examine how the distribution of redox-sensitive compounds evolves from steady to transient state after freshwater sediments were colonized by bioturbating tubificid worms, while Ekeroth et al. (2012) explore the impact of oxygen and diverse benthic macrofauna



Fig. 3 Bjørn savoring oysters in the company of close friend and collaborator Alfonso Mucci. Bjørn and Al have been working together for almost 30 years now, and their friendship is the cement of their success. In our eyes, they exemplify the value of teamwork and camaraderie in science (Photo by B. Deflandre) 
species on the flux of phosphate through the sediment-water interface. Cathalot et al. (2012) investigate the impact of fish farming on sediment biogeochemical cycles and the consequent enrichment of organic matter in the underlying sediments in a Scottish Loch. Viktorsson et al. (2012) measured in situ fluxes of soluble reactive phosphorus in sediments of the Gulf of Finland and Baltic Sea using autonomous benthic landers. Finally, Macdonald and Gobeil (2012) offer an alternative to the interpretation of $\mathrm{Mn}$ and $\mathrm{Fe}$ profiles in the Arctic Ocean, linking sea level variations to organic carbon enrichments in slope and deep Arctic sediments. We thank all of the contributing authors, and, of course, we thank Bjørn for all he has done for us personally and for the field of Chemical Oceanography.

\section{References}

Anschutz P, Ciutat A, Lecroart P, Gérino M, Boudou A (2012) Effects of tubificid worm bioturbation on freshwater sediment biogeochemistry. Aquat Geochem 18:475-497

Cathalot C, Lansard B, Hall POJ, Tengberg A, Almroth-Rosell E, Apler A, Calder L, Bell E, Rabouille C (2012) Spatial and temporal variability of benthic respiration in a Scottish sea loch impacted by fish farming: a combination of in situ techniques. Aquat Geochem 18:515-541

Ekeroth N, Lindström M, Blomqvist S, Hall POJ (2012) Recolonisation by macrobenthos mobilises organic phosphorus from reoxidised Baltic Sea sediments. Aquat Geochem 18:499-513

Lefort S, Mucci A, Sundby B (2012) Sediment response to 25 years of persistent hypoxia. Aquat Geochem 18:461-474

Macdonald RW, Gobeil C (2012) Manganese sources and sinks in the Arctic Ocean with reference to periodic enrichments in basin sediments. Aquat Geochem 18:565-591

Sundby B (1977) Manganese-rich particulate matter in a coastal marine environment. Nature 270:417-419

Sundby B, Silverberg N, Chesselet R (1981) Pathways of manganese in an open estuarine system. Geochim Cosmochim Acta 45:293-307

Viktorsson L, Almroth-Rosell E, Tengberg A, Vankevich R, Neelov I, Isaev A, Kravtsov V, Hall POJ (2012) Benthic phosphorus dynamics in the Gulf of Finland. Baltic Sea Aquat Geochem 18:543-564 